\title{
BALING STORAGE METHOD: PAST, PRESENT AND SWEDISH EXPERIENCE
}

\author{
William Hogland \\ Marcia Marques \\ Velma Grover \\ University of Kalmar, Sweden
}

\section{INTRODUCTION}

Baling is a process through which compaction (saving of space) is achieved for ease of handling, for better and optimum transportation (because of compaction, more stuff can be loaded). Baling has been practiced for a long time by the farmers - farmers used the baling process for managing hay and cotton. When used in case of lint, the bale meant 392 pounds of lint. Baling of yam was of three types:

- Soft bales - the yam was packed in bags for transport to small distances.

- Pressed bales - in this yam is subject to moderate pressure for transport to considerable distances for domestic trade.

- Bundling and baling - the yarn is made into bundles and pressed into bales for export reason

Besides, the farmers - recycling industry has used baling since a long time. Some of the ways in which recycling industry have used are:

- Iron (ferrous metal) - During the baling process ferrous metals are separated with the help of rotary drum magnet which separates out the metal from the other waste.

- Paper - Some baling plants separate out the paper - the paper from the waste stream and other separated out waste is pressed into bales and sold to the paper mills for recycling. This has been carried out in India for a long time - when instead of mechanical balers, the papers were pressed into bales manually and sold to paper mills for recycling or was recycled at small scale plants at home.

\section{Solid waste management}

Probably, solid waste management is the latest addition to baling industry. Baling of solid waste management first started in U.S. and Japan. Baling was used in Europe for the first time, in 1976, in Glasgow. In the earlier days baling was of two types - the medium pressure and high pressure baling. In the medium pressure baling - the waste was compressed to reduce the volume and to eliminate void - which ultimately crushed the material. The ejected bale was tied with a number of steel wires. In high density baling - self- sustaining bale was produced. A self- sustaining bale had no steel wires, which were tied in the case of highpressure bales, and therefore they tended to expand after ejection. The wire tied bales proved 
to be stronger than the self- sustaining bales. On dropping, the wired tied bales deformed less than the high-pressure self-sustaining bales.

It was discovered that most of the materials could be baled - except things like concrete, steel beams, truck tires, large carpets and large plastic rolls. Baling has a long history of application for plastic and other types of scraps. This is done mostly for the advantages like compaction, ease of handling and transportation and still sold immediately - from scarp to cash. As discussed by Seiger and Kewitz (1997), they suggested temporary storage prior to collecting (hotels, hospitals etc), one of the possible uses of baling.

\section{Baling as energy storage}

Relatively recently, it has been suggested that baling can be (has been) used to store energy for future use or to reduce the volume of waste going to landfill sites or both. Baling can be of different types - baling for short-term use, or for long-term use. In Arkansas in the U.S., it has been reported that balers are used for reducing the volume of the waste at the landfill sites they compact the waste in the balers but then take it out from the balers to landfill them in the cells of the landfill site. For a while, baling has been practiced on landfill sites to reduce the amount of waste at landfill sites in Italy also. Baling just for compaction has become a common practice at many places in North America and Europe.

But for the sake of this article baling refers to the compaction or compression of waste to store it for the future energy use or to store the recyclable to recycle them when needed. One of the advantages of storing the recyclable this way is that it is a neat, clean and tidy way to handle the waste and if done properly (properly compacted with ventilation) it also reduces the risk of self ignition and save from the incidents of fire (For example a fire in Delhi at Jawalapuri - the market for buying and selling of recyclable plastic caused a lot of air pollution and sickness in the neighborhood areas besides the huge financial loss. Had this plastic been stored as bales, the damage would not have been that extensive).

\section{Advantages of baling}

Some of the advantages of baling can thus be summed up as follows:

- Store energy for the future

- clean, tidy and safe, risk of self ignition is reduced

- transportation is easier - can do it in ordinary truck

- reduce area of landfill required - and in a way reduce the cost of transportation, and other costs involved with landfill

- lesser amount of cover soil is required for the baled waste - because loose waste covers larger area than the baled waste

- no blowing trash collection cost is involved with baled waste

- stability during the storage

- almost no energy and mass loss

\section{Types of bales}

Balers could be viewed in a number of ways - like. There are three types of balers:

- Handeheld

- Vertical

- Horizontal

Hand held balers are used all over the world - but the most extensive use is in developing countries like India. Household personal items like under-wears, sweaters and other items like these are packed in soft cardboard boxes. A town of town retailer has to ship these items from 
whole sale market like Delhi. Baling these items would not only damage the boxes, but there are chances that the merchandise would get damaged also. So these goods are packed in a wooden box which is not so strong. Therefore, putting wires around it using hand held baler strengthens it. This is just one of the examples, other examples could be cited also - but that is enough. This way, the goods can be shipped in cheap and compact fashion. Whether the feed is vertical or horizontal determines the other two types of balers. Another criteria would be the type or shape. Concerning shape, bale can be classified as:

- Based on end types - Closed or open-end types.

- On the basis of shape - cylindrical, rectangular

The closed end baler has a door at the end of the chamber while the open-end baler pushes the bale out and requires an "auto-tie" system. Auto-tie balers are further of three types horizontal. single-ram or two-ram. In this kind of auto-tie baling, actually the bales of waste are ejected out in the chamber and therefore this type is not discussed any further in this article

The density of baled waste depends upon the configuration of baler and waste characteristics Although balers can save a waste processing facility time and money by reducing disposal costs. improving operational efficiency and extending the life of a landfill site, it should be clearly determined if a baler is needed and which kind of baler is needed. Another important decision -where would it be done at transfer station or at the landfill site should be answered before deciding on which baler to buy.

\section{Selection criteria for baling}

The following factors should be taken into consideration:

- daily amount of waste received

- density desired from compaction (bales tend to expand when taken out of chambers at landfill site but then again undergo some compaction when placed on the landfill sites because of pressure from other bales)

- whether or not recyclable would be baled

- predictions of future waste volumes

- budget restrictions

- shape and size of the materials to be baled - what will be the largest piece of waste to be baled

- if the waste would be shredded or not

- will there be enough volume for conveyor feed or would it hand fed

- if the bales would be made at transfer stations, what kind of vehicle would be needed to transport those

\section{Swedish experience}

In Sweden (according to the Swedish Waste Management Association), around 2.7 million tonnes of municipal solid waste and 4.5 million tonnes of industrial waste are produced per year but 1.35 million tonnes of municipal solid waste and 4.15 million tonnes of industrial waste are landfilled. This is attributed to the insufficient capacity of incinerator plants to handle this much of waste. So, it is in considered to be advantageous to store waste in summers and consume it in winters when more energy is needed.

In Sweden baling has been practiced since 1992. The machines are fully computerized and the waste is hydraulically pressed into rolls, which are rolled into a polyethylene net and wrapped 
by polyethylene. The main purpose of baling of waste in Scandinavian countries (as mentioned earlier) is to store the waste to incinerate in winters, because more energy is needed in winters than in summers. Some experiments have been done in Sweden. More studies are being carried to improve the baling process and to study the use of it for the recyclable materials.

\section{MATERIAL AND METHODS}

Waste can be stored in non-compacted form or compacted form. One of the compacted forms can be baling. When the bales are made they can be cylindrical or rectangular (or may be square). These bales are stored at the sites in the piles of maybe up to 3 to 5 meters high.At the experiments done at Nossebro (where bales were placed indoors so the temperature was relatively constant) and Helsingborg (where bales were placed outside), different kind of waste was examined which included:

- unsorted municipal solid waste

- municipal solid waste with increased moisture

- mechanically sorted RDF

- RDF with an increased moisture

The composition of waste at Nossebro site is given in Table 1. In this case both unsorted municipal solid waste and RDF are studied. The first column shows percentage for unsorted waste and shows a high percentage of waste consists of phytomass. The second column shows the percentage composition of RDF, which is the mechanically separated waste - where the waste is crushed and the metals pieces were magnetically separated.

Table 1. The waste composition at Nossebro, Sweden (1999):

\begin{tabular}{lcc}
\hline Composition & $\begin{array}{c}\text { Weight \% (dry basis) } \\
\text { household waste }\end{array}$ & RDF \\
\hline Paper, wood, textile and burnable & 66 & 87 \\
\hline Plastics & 16 & 12 \\
\hline Metal, glass, sand and not burnable materials & 17 & 1 \\
\hline Dry substances (wt \%) & 54.4 & 37.9 \\
\hline Moisture (wt \%) & 45.6 & 62.1 \\
\hline Ash (wt \% dry weight) & 24.2 & 14.8 \\
\hline Calorific value (net, MJ/kg) & 8 & 5 \\
\hline Density of bale $(\mathrm{kg} / \mathrm{m} 3)$ & 650 & 718 \\
\hline
\end{tabular}

In this study besides these bales - two other bales were studied in which both unsorted waste and RDF was soaked in water prior to baling. This was done to study the effect of increased moisture. The composition of waste at Helsingborg is given in Table 2. 
Table 2. The waste composition at Helsingnborg, Sweden.

\begin{tabular}{|c|c|c|c|}
\hline Composition & $\begin{array}{c}\text { Bale H3 } \\
\text { Weight \% (dry basis) }\end{array}$ & $\begin{array}{c}\text { Bale H1 } \\
\text { Weight \% (dry basis) }\end{array}$ & $\begin{array}{l}\text { Average in Sweden } \\
\text { Weight \% (dry basis) }\end{array}$ \\
\hline $\begin{array}{l}\text { Wood, cardboard, textile, } \\
\text { packaging, leather }\end{array}$ & 73.5 & 82.5 & 79 \\
\hline Plastics, rubber & 25 & 17 & 7 \\
\hline Metal, glass & 1 & - & 9 \\
\hline Others & 0.5 & 0.5 & 5 \\
\hline dry mass & 78 & 81 & 70 \\
\hline ash content & 16 & 8 & + \\
\hline Effective heat value $(\mathrm{MJ} / \mathrm{kg})$ & 16.6 & 12.8 & 8 \\
\hline
\end{tabular}

The last column shows the average waste composition in Sweden and the first two columns show the percentage composition of waste in the bales under study. Most part of the waste is again wood, cardboard, and paper. As it is sorted waste the amount of metal is low.

\section{RESULTS}

Only the bales in the shaded area got fungal or algae growth, others were fine. But even in these no harm to the waste. Very little or no methane produced because as can be seen from the above discussion the temperature went beyond 70 , the moisture content was low, the $\mathrm{pH}$ was lower than 6.4 (optimal pH as reported by Kotez for methane production is $6.4-7.2$ ), as the reaction is stopping at the acidic phase may be the amount of $\mathrm{CH} 3 \mathrm{COOH}$ is more than $3000 \mathrm{mg} / \mathrm{l}$. Or may be there is a direct oxidation of organic matter to carbon dioxide or may be methane what ever is formed is undergoing oxidation. Some of the reasons sited by Seiger and Kewitz (1997) for no anaerobic degradation inside wrapped bales are:

- the inside of the bale is too acidic for the microorganism to grow.

- the methanogenic bacteria have to build symbiosis to work together with hydrolytical bacteria (acidogenic and acetogenic bacteria) in order to degrade the high moleculary material; by shredding and baling of waste, symbiosis is interrupted.

- the water content due to evaporation is not high enough to support bacterial metabolism.

Energy content of waste material after storage is shown in Table 3. All the bales with $\mathrm{H}$ are from site Helsingborg. $\mathrm{L}$ is stored in laboratory and bales with $\mathrm{N}$ are from site Nossebro.

Table 3. Energy content of waste material after storage.

\begin{tabular}{cc}
\hline Bales & Effective Calorific value \\
\hline H1 & 17.7 \\
\hline H3 & 13.8 \\
\hline N1 & 13.2 \\
\hline N2 & 13.2 \\
\hline N6 & 10.3 \\
\hline N7 & 9.4 \\
\hline
\end{tabular}


It can be seen from the table that total mass loss is most in case of bale N7 with shredded waste and incidentally this has got maximum moisture weight percentage.

It was observed that the temperature in bales $\mathrm{N} 1$ and $\mathrm{N} 2$ rise eventually, and a maximum is raised after three months (100.days) while in bales N6 and N7 in case of shredded waste - the temperature shoots up immediately and another peak is observed after 100 or 120 days. In bale $\mathrm{N} 1$ carbon dioxide is maximum in the first 30 days and then percentage remains quite steady, no methane is produced in bales $\mathrm{N} 1$ and N2, while methane is produced in bales N6. N7 and L1. In case of bale N6 immediately a lot of carbon dioxide is produced but then the amount of carbon dioxide is reduced as methane is produced (which is after 90 days), in case of N7, although methane is produced but the amount of carbon dioxide is not really reduced like in case of bale N6. A low amount of methane is produced in case of bale L1 and is observed even in first month. It can be concluded that the methane is produced in case of RDF while nothing was observed in case of household waste.

Table 5 shows the losses in calorific values (\% net value) related to different storage conditions in Umeå, Northern Sweden.

Table 4. Characteristics of bales from Nossebro site.

\begin{tabular}{lccccc}
\hline Characteristics & $\mathrm{N} 1$ & $\mathrm{~N} 2$ & $\mathrm{~N} 6$ & $\mathrm{~N} 7$ & L1 \\
\hline $\begin{array}{l}\text { Weight of the bale }(\mathrm{kg}) \\
\text { as on } 14^{\text {th }} \text { Feb 95 except L1 }\end{array}$ & 976 & 914 & 1035 & 1130 & $\begin{array}{c}870 \text { (as on 4 } \\
\text { Aug 94) }\end{array}$ \\
\hline $\begin{array}{l}\text { Total mass loss (kg) } \\
\text { as on 8 } 8^{\text {th }} \text { Aug 95 except L1 }\end{array}$ & 8 & 8 & 10 & 30 & $\begin{array}{c}27 \text { (as on } \\
18^{\text {th }} \text { Aug 95) }\end{array}$ \\
\hline Material (waste) & household & household & RDF & RDF & \\
\hline pH in leachate & 4.2 & 4.6 & 4.6 & 4 & 3.9 \\
\hline pH on surface of waste & 5.5 & 5.5 & 6 & 5.8 & 5.5 \\
\hline moisture (wte) & 45 & 45 & 47 & 62 & $\begin{array}{c}28 \text { (as on } \\
18^{\text {th }} \text { Aut 95) }\end{array}$ \\
\hline Initial moisture (wte\%) & & & & & 31 \\
\hline
\end{tabular}


Table 5. Storage conditions and losses in calorific value (bales at the power station in Umeå).

\begin{tabular}{|c|c|c|c|c|}
\hline Type of waste & $\begin{array}{l}\text { Storage } \\
\text { conditions }\end{array}$ & $\begin{array}{l}\text { Storage time } \\
\text { (months) }\end{array}$ & $\begin{array}{c}\text { Loss of calorific } \\
\text { valuet }(\% \text { net value })\end{array}$ & $\begin{array}{c}\text { Max } \\
\text { Temp (C) }\end{array}$ \\
\hline \multirow[t]{3}{*}{ CRDF (fluff) } & High mound* & 5 & 37 & 78 \\
\hline & High mounds* & 9 & 54 & - \\
\hline & In a tent & 9 & + & - \\
\hline \multirow[t]{6}{*}{ DRDF (pellets) } & Wooden boxes* & 7 & 9 & 70 \\
\hline & Wooden boxes* & 11 & 12 & $\circ$ \\
\hline & In a tent & 11 & 10 & 42 \\
\hline & In a tent & 7 & 15 & 55 \\
\hline & High mounds* & 5 & 23 & - \\
\hline & High mounds* & 9 & 49 & $=$ \\
\hline \multirow[t]{4}{*}{ Fraction dry solids } & Wooden boxes* & 5 & 0 & 28 \\
\hline & In a tent & 5 & 16 & - \\
\hline & High mounds* & 6 & 28 & 72 \\
\hline & Wooden boxes & 6 & 28 & 72 \\
\hline $\begin{array}{l}\text { Unsorted household } \\
\text { waste }\end{array}$ & $\begin{array}{l}\text { Plastic covered } \\
\text { bales }\end{array}$ & 8 & 1 & 25 \\
\hline $\begin{array}{l}\text { RDF (milled \& } \\
\text { mechanically sorted } \\
\text { from household waste) }\end{array}$ & $\begin{array}{c}\text { Plastic covered } \\
\text { bales }\end{array}$ & 6 & $\mathrm{t}$ & 25 \\
\hline
\end{tabular}

\section{CONCLUSIONS}

It would appear that baling is a safer way to store solid waste compared to storage piles, regarding risk of self- ignition (Hogland and Marques, 1999). Besides, it can be stored away in more compact form - thus requiring lesser storage space. The waste could thus be used where and when the energy is required. It is still not quite clear, what the effects are on calorific value over long period of time (more than 6 months). Therefore more experiments are required to ascertain whether it is worthwhile to store the waste and the optimum period for storage. A new baling projects testing and comparing round bales with rectangular bales has just been started.

\section{REFERENCES}

Hogland, W. \& Marques, M. (1999). Physical, biological and chemical processes during storage and spontaneous combustion of waste fuel (submitted).

Babar, Abdul Aziz Khan

Report on the cost of ginning and pressing cotton in west Punjab

Published by the board of economic inquiry, West Pun.jab, 1948

Barber ,Bethany

Baler Trends how does your measure up?

Baler Trends 7-98, July 1998 
Coblentze, W.K., J.O. Fritz and K.K. Bolsen

Baling system for making laboratory scale hay bales

Agron. J. 85:962-965 (1993)

DOI: https://doi.org/10.2134/agronj1993.00021962008500040032x

Hogland, William, Ingrid Persson, Per Pettersson, Torleif Bramryd

Lagring av avfallsbranslen

Industri - och hushallsavfall, Lund 1993

Hogland, William, Torleif Bramryd and Ingrid Persson

Physical, Biological and chemical effects of unsorted fractions of industrial solid waste in waste fuel storage.

Waste Management and Research (1996) 14, 197-210

DOI: https://doi.org/10.1 177/0734242X9601400209

Mancuso, I., F. De Poli, V. Antonietti and C. Gallina

Balefilling: Effects on landfill management leachate and biogas yield

Montague, David J., and John T. Baker

Baling out small landfills

Waste Age, January 1998

Persson,Ingrid, Feraydoon Tamaddon, William Hogland, Farhad Kalantari, Christer Lundgren, Lars Nystrom

Lagring av brannbart sorterat bygg - och rivningsavfall

Lund 1994

Sieger, E., and H.J. Kewitz

Application of baling technology for temporary storage of household waste

Proceedings Sardinia 97, $6^{\text {th }}$ International Landfill Symposium, Cagliari, Italy

Tamaddon, Feraydoon, William Hogland and Jan Kjellberg

Storage of waste-fuel by baling technique

Lund University, Lund 1995

Technical and environmental advantages in mechanical baling as a disposal option Mimeo, Institute of Waste Management 